\title{
Influence of Fall-applied Treatments on Spring Transition of an Overseeded Bermudagrass Green
}

Robert L. Green, ${ }^{1}$ Grant J. Klein, Francisco Merino, and Victor Gibeault Department of Botany and Plant Sciences, University of California, Riverside, CA 92521-0124

Additional index words. seedbed preparation, trinexapac-ethyl, diquat, perennial ryegrass, rough bluegrass

Abstract. Bermudagrass [Cynodon dactylon (L.) Pers x C. transvaalensis Burtt-Davy] greens across the southern United States are normally overseeded in the fall to provide a uniform green playing surface and tolerance to wear during winter bermudagrass dormancy. The spring transition from overseed grass back to bermudagrass is a major problem associated with overseeding because there can be a decline in putting green quality and playability. There have been recommendations, but relatively few published reports, on the effect of treatments associated with seedbed preparation and overseeding on bermudagrass spring transition. The objective of this 2-year study was to determine if spring transition of an overseeded 'Tifgreen' bermudagrass green was influenced by fall-applied scalping level, chemical, and seed rate treatments. Treatment factors and levels were designed to reflect the range of practices used by golf course superintendents in the region at the time of the study. The green was located in the Palm Springs, Calif. area, which has relatively mild winters and a low desert, southern Calif. climate. The first year of the study was from September 1996 to July 1997 and the second year was from September1997 to July 1998. Scalping level treatments included a moderate and severe verticut and scalp; chemical treatments included a check, trinexapac-ethyl at two rates, and diquat; and seed rate treatments included a high and low rate of a mixture of 'Seville' perennial ryegrass (Lolium perenne $\mathbf{L}$.) and 'Sabre' rough bluegrass (Poa trivialis L.). The plot was maintained under golf course conditions and a traffic simulator was used to simulate golfer traffic. Visual ratings of percent green bermudagrass coverage were taken every 3 weeks from 20 Feb. 1997 to 29 July 1997 and from 11 Nov. 1997 to 22 July 1998. Visual turfgrass quality ratings were taken during the second year of the study. Results showed that spring transition was not influenced by fall-applied treatments during both years. Also, visual turfgrass quality was not influenced during the second year. Chemical names used [4(cyclopropylhydroxy-methylene)-3,5-dioxocyclohexanecarboxylic acid ethyl ester (trinexapac-ethyl); 9,10-dihydro-8a-, 10a-diazoniaphenanthrene (diquat).

Bermudagrass greens across southern United States are normally overseeded in the fall to provide a green uniform playing surface and tolerance to wear during winter bermudagrass dormancy. Spring transition from cool-season overseed grass back to bermudagrass is a major problem associated with overseeding because there can be a decline in putting green quality and playability. Ideally, spring transition would be gradual and predictable without visible signs of dormant bermudagrass. Unfortunately, the transition can be unpredictable with either a sudden loss of overseed grass before bermudagrass coverage or the overseed grass lives too long, competing with the bermudagrass and slowing its recovery.

Research to improve spring transition has been directed toward practices during both the spring and fall with more published work

Received for publication 8 Nov. 2002. Accepted for publication 6 Aug. 2003. We thank Lane Stave and Will Friedner, golf course superintendents at Desert Horizons Country Club, Indian Wells, Calif., for their assistance with field plot maintenance and research activity support.

${ }^{1}$ To whom reprint requests should be addressed; e-mail robert.green@ucr.edu. cal method of removing overseed grass and improving bermudagrass transition (Horgan and Yelverton, 2001; Johnson, 1994a, 1990, 1988; Mazur, 1988). Two herbicides-pronamide [3,5-dichloro-N-(1,1-dimethyl-2-propynyl)-benzamide] and diclofop ( $)-2[4$ (2,4-dichlorophenoxy)phenoxy] propanoic acid-seem to be effective for hastening spring transition, but success depends on rates and timing of applications.

Recommendations for an improved spring transition also include practices during the fall that promote a good density of bermudagrass lateral stems, especially rhizomes, that are well into the process of accumulating and storing carbohydrates. Dunn and Nelson (1974) reported that bermudagrass total carbohydrates and sucrose increased in lateral stems during fall as hardening occurred. They also reported that stolons appeared to be the principal overwintering storage organ for carbohydrates and source of energy for regrowth in spring. Though the association between bermudagrass spring greenup and transition has not been reported, there are reports that show a significant correlation between bermudagrass rhizome density and average spring greenup (Krans et al., 1992) and between concentration of stored carbohydrate and number of rhizomes near the soil surface during winter and early spring (Dunn et al., 1980).

There are relatively few published reports on the effects of treatments associated with seedbed preparation and overseeding of bermudagrass on spring transition. In terms of seedbed preparation, Gill et al. (1967) reported that mowing, vertical mowing, and topdressing did not affect spring recovery of an 'Ormond' bermudagrass [Cynodon dactylon (L.) Pers.] sod managed under home lawn conditions. In a second study involving different overseed grass species and seeding rates, Gill et al. (1967) reported that mowing at seedbed preparation reduced spring recovery of ' $U-3$ ' bermudagrass [Cynodon dactylon (L.) Pers.] maintained under home lawn conditions. They concluded that bermudagrass recovery reduction may have been due to increased stand of overseed grass as a result of the mowing treatment. Johnson (1986) reported that vertical mowing treatments and ethofumesate [( $)$-2-ethoxy-2,3-dihydro-3,3-dimethyl-5benzofuranyl methanesulfonate)] applications at seeding slowed spring transition of a 'Tifway' bermudagrass green. In other work involving chemicals with herbicide activity, Johnson (1994b) reported that spring transition of a 'Tifway' bermudagrass green, overseeded with rough bluegrass, was not affected if fenarimol a-(2-chlorophenyl)-a-(4-chlorophenyl)-5-pyrimidinemethanol was applied $\geq 2$ weeks before overseeding. Johnson (1987) also reported that when tricalcium arsenate was applied at various rates and months, ranging from August to December, spring transition of an overseeded 'Tifway' bermudagrass green overseeded with perennial ryegrass was hastened for some treatments in May but there were no differences among treatments in June and July.

In terms of the effect of overseed grass selection and seeding rate on bermudagrass 
spring transition, Gill et al. (1967) reported that creeping red fescue (Festuca rubra L.) reduced bermudagrass spring recovery more than annual ryegrass (Lolium multiflorum Lam.) or kentucky bluegrass (Poa pratensis L.) when overseeded on 'Ormond' or 'U-3' bermudagrass maintained under home lawn conditons. Mazur and Rice (1999) reported that spring transition of a 'Tifgreen' bermudagrass green was slowed at high $\left(1,500\right.$ to $\left.1,800 \mathrm{~kg} \cdot \mathrm{ha}^{-1}\right)$ seeding rates of perennial ryegrass.

The Palm Springs, Calif., area, home of over 100 golf courses, is an important resort golf market. The reputation and expectation for excellent overseeded bermudagrass golf courses are high during the resort season which runs from November through May, though there has been a recent trend of more play extending into the summer. Relatively mild winters of this low desert climate of southern Calif. are a basis for a resort season. Due to these expectations, golf course superintendents conduct rather aggressive practices associated with bermudagrass seedbed preparation and overseeding. These practices have included induction of partial bermudagrass dormancy by reducing irrigations in August and September; applications of diquat before seedbed preparation to dessicate the bermudagrass; severe verticutting and scalping practices that result in no green bermudagrass coverage and exposure of soil; and relatively high seeding rates. Many private golf courses are closed and overseeded in late September to early October and then reopened for play in early November.

Slow spring transition is a major problem on golf courses in the Palm Springs area and across the southern United States. It would be desirable to use less aggressive practices associated with seedbed preparation and overseeding if it resulted in similar turfgrass quality and improved spring transition. The objective of this study was to determine if spring transition of an overseeded 'Tifgreen' bermudagrass green was influenced by fall-applied scalping level, chemical, and seed rate treatments.

\section{Materials and Methods}

This study was conducted on an out-ofplay 'Tifgreen' bermudagrass putting green located at Desert Horizons Country Club, Indian Wells, Calif. (Palm Springs area). The green was established from sprigs during the summer of 1989. A soil test of the upper $15 \mathrm{~cm}$ was taken during the study and showed that the modified root zone was $85 \%$ sand, $11 \%$ silt, $4 \%$ clay, and $0.56 \%$ organic matter. The firs year of the study was from September 1996 to July 1997 and the second year was from September 1997 to July 1998.

Treatment factors and levels were designed to reflect practices of golf course superintendents in the region at the time of the study. They were arranged in a split split-plot design with four replications and included two scalping level treatments applied on $3.0 \times 7.3-\mathrm{m}$ main plots, four chemical treatments applied on 1.8 $\times 3.0$-m subplots, and two seed rate treatments applied on $1.5 \times 1.8-\mathrm{m}$ sub-subplots. Treatments were applied to the same plots during both years. Before the application of treatments for the second year, a visual assessment of bermudagrass coverage did not indicate treatment carry over effects from the first year.

Treatments were applied in the same chronological order each year: chemical, scalping level, and then seed rate. Chemical treatments were applied on 27 Sept. 1996 and 22 Sept. 1997 and included a check, trinexapac-ethyl at $290 \mathrm{~g} \cdot \mathrm{ha}^{-1}$ a.i. and $97 \mathrm{~g} \cdot \mathrm{ha}^{-1}$ a.i., and diquat at $560 \mathrm{~g} \cdot \mathrm{ha}^{-1}$ a.i. plus a nonionic spreader. All applications were made with a backpack $\mathrm{CO}_{2}$ pressurized sprayer calibrated to deliver $815^{2} \mathrm{~L} \cdot \mathrm{ha}^{-1}$

Scalping level treatments were applied on 4 Oct. 1996 and 29 Sept. 1997. The moderate scalping level treatment consisted of four passes with a triplex mowing unit equipped with verticut units set at a 3.2-mm bench height and one pass with a triplex mower set at a $2.8-\mathrm{mm}$ cutting height. The severe scalping level treatment consisted of all activities of the moderate treatment plus two passes with a walk behind reel mower set at a 2.5-mm cutting height. Visual ratings, taken immediately after treatment application in 1997, showed that the moderate and severe scalping levels had an average $41 \%$ and $2 \%$ green bermudagrass coverage, respectively. In 1996 these ratings were taken $5 \mathrm{~d}$ after treatment application and are not reported because most shoots that were green immediately after treatment application turned brown $5 \mathrm{~d}$ later.

Seed rate treatments were applied by hand 12 Oct. 1996 and 10 Oct. 1997. The high rate of seed consisted of a mixture of 'Seville' perennial ryegrass and 'Sabre' rough bluegrass at a rate of $1,746.6$ and $458.6 \mathrm{~kg} \cdot \mathrm{ha}^{-1}$ pure live seed (PLS), respectively. The low rate of seed was 'Seville' and 'Sabre' at a rate of 1,088.8 and $458.6 \mathrm{~kg} \cdot \mathrm{ha}^{-1} \mathrm{PLS}$, respectively. Beard (2002) reported that perennial ryegrass and rough bluegrass had a mean $584 \times 10^{3}$ and $6,336 \times 10^{3}$ seeds per kilogram, respectively. On a PLS basis, the high seed rate was $26 \%$ perennial ryegrass and $74 \%$ rough bluegrass, while the low seed rate was $18 \%$ perennial ryegrass and $82 \%$ rough bluegrass. After seeding, the green was topdressed with an 8-mm layer of sand.

After germination, the plot was initially mowed at a 7.9-mm cutting height and was gradually lowered to a $2.7-\mathrm{mm}$ cutting height during October to January. The plot was mowed daily with a walk behind greens mower and fertilized with a $15.0 \mathrm{~N}-2.2 \mathrm{P}-6.6 \mathrm{~K}$ fertilizer at a $\mathrm{N}$ rate of $14.6 \mathrm{~kg} \cdot \mathrm{ha}^{-1}$ every 3 weeks. Irrigation was provided to prevent visual drought symptoms

A traffic simulator was used to simulate golfer traffic from 20 Dec. 1996 to 7 July 1997 and from 17 Nov. 1997 to 29 June 1998. It was built from a $50.8 \mathrm{~cm}$-wide reel mower frame and had 38.1- and 48.3-cm-diameter drums with golf shoe metal spikes attached to them. Traffic was applied 1 pass per day, $3 \mathrm{~d}$ per week. A visual assessment indicated that spike hole density on the test putting green appeared similar to putting greens on the golf course.

Visual turfgrass quality was taken during the second year of the study on 2 Dec. 1997 and 9 Feb., 20 Mar., 18 May, and 1 July 1998. A scale of 1 to 9 was used with $1=$ poorest, $5=$ minimally acceptable, and $9=$ best overseeded bermudagrass putting green. These ratings were not taken during the first year of the study.

Visual ratings of percent green bermudagrass coverage were taken every 3 weeks from 20 Feb. to 7 July 1997 (first year) and from 11 Nov. 1997 to 22 July 1998 (second year). Ratings were taken by carefully inspecting the shoots within two $104-\mathrm{cm}^{2}$ areas within each
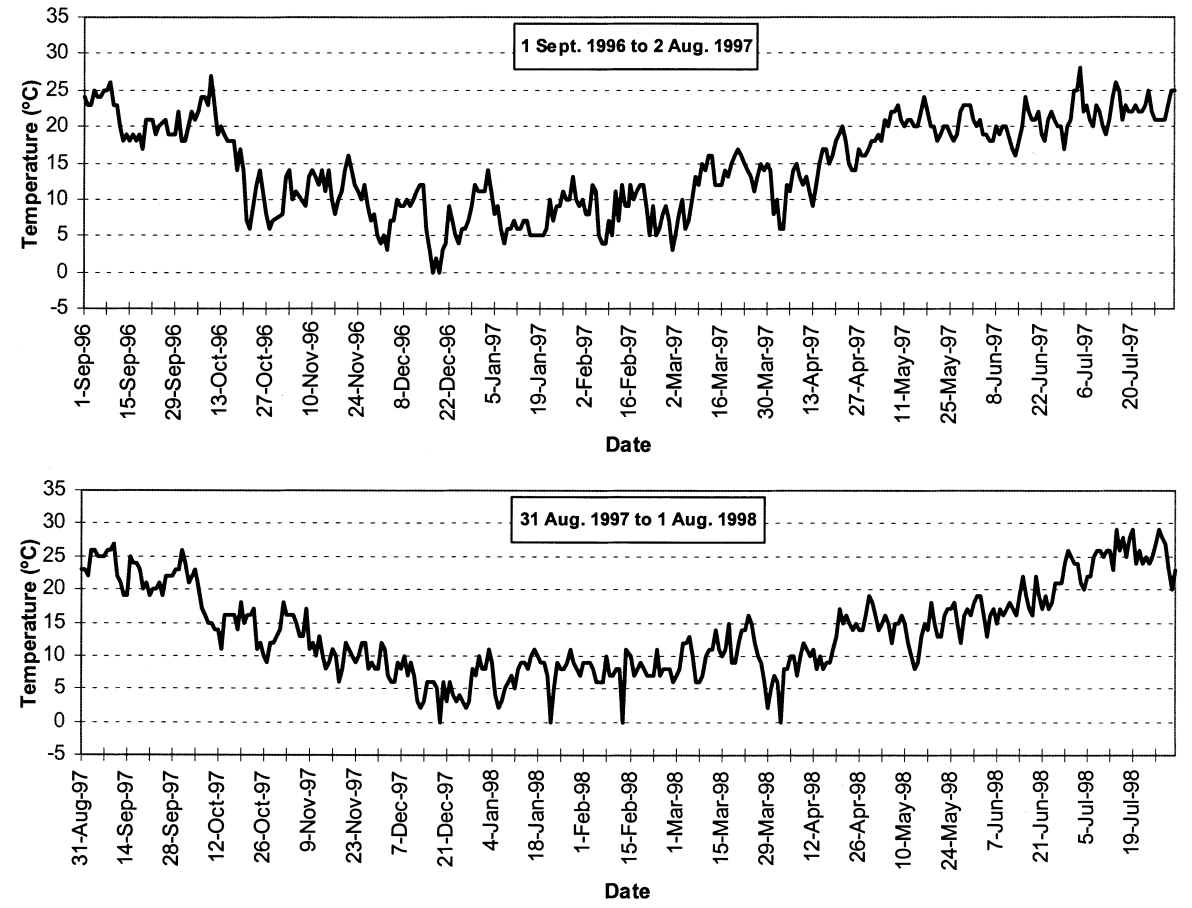

Fig. 1. Daily minimum air temperatures in Cathedral City, Calif., from 1 Sept. 1996 to 2 Aug. 1997 and from 31 Aug. 1997 to 1 Aug. 1998. 
sub-subplot. Approximately $15 \%$ and $5 \%$ of measurements required third and fourth subsamples, respectively to insure that each average measurement consisted of two subsamples that did not differ by $>5 \%$. This subsampling procedure was confirmed by a statistician (C.J. Adams, personal communication). Visual ratings of the entire plot were not possible until late spring/early summer because turfgrass coverage was predominantly rough bluegrass and it was not possible to distinguish between green bermudagrass and perennial ryegrass. The accuracy of these ratings is supported by several points. First, Dest and Guillard (1987) reported that either visual ratings of the entire plot or plant separations from three, $25.5-\mathrm{cm}^{2}$ plugs per plot could be used to determine changes in community composition of a fairway composed of bentgrass (Agrostis spp.) and annual bluegrass. We believe the method used in this study of carefully inspecting the shoots in a total area of $208 \mathrm{~cm}^{2}$ compares to the method used by Dest and Guillard (1987) of separating plants from a total area of 76.5 $\mathrm{cm}^{2}$. The second point is that we found no significant $(P \geq 0.05)$ difference between the methods of visual inspection of shoots within two $104-\mathrm{cm}^{2}$ areas and visual estimates of the entire plot on 1 July and 22 July, 1998 rating dates. A linear additive model for the paired comparison (Steel and Torrie, 1960) was used to compare the two measurement methods for individual dates. A third point is that Dest and Guillard (1987) also used a square grid method and reported significant statistical correlations among the three methods they used to assess plant populations. Their square grid method had a similar basis to a modified vertical point quadrant method used by Gaussoin and Branham (1989) to assess the change in percentage annual bluegrass in a mixed stand of annual bluegrass and creeping bentgrass.

Air temperatures were collected from a California Irrigation Management Information System (CIMIS) weather station located in Cathedral City Calif., which is located $\approx 13$ km from Desert Horizons Country Club.

An analysis of variance (ANOVA) was conducted for each date for visual turfgrass quality and percent green bermudagrass coverage. A general linear ANOVA was used to test main effects and interactions. Means were compared by using a Fisher's protected LSD test.

\section{Results}

Daily minimum air temperatures during the study show that winters were relatively mild in the low desert climate of southern California (Fig. 1). There were relatively few days in which daily minimum temperature was $\geq 0{ }^{\circ} \mathrm{C}$. As a point of reference, two studies reported on the resistance to freezing stress of 'Tifgreen' bermudagrass. Reeves et al. (1970) reported no winter kill on turf plots in College Station, Texas with a low temperature of -8 ${ }^{\circ} \mathrm{C}$ while Ibitayo et al. (1981) reported low temperature killing points of stolons taken on various months from field plots in Fort Collins, Colo.: $-2{ }^{\circ} \mathrm{C}$ (18 Oct.); $-6^{\circ} \mathrm{C}(15$ Nov. $) ;-9{ }^{\circ} \mathrm{C}$ (14 Dec.); and $-11{ }^{\circ} \mathrm{C}$ (13 Jan.).

Visual turfgrass quality on all rating dates during the second year was not significantly affected by scalping level, chemical nor seed rate treatments (data not shown). The mean rating over all treatments for each date was 6.0 (2 Dec. 1997), 7.3 (9 Feb. 1998), 8.0 (20 Mar., 7.0 (18 May), and 6.3 (1 July). There was only one significant interaction on one date, scalping level by chemical on 2 Dec. The general quality of the putting green was similar during the first year, though ratings were not taken to substantiate this observation.

With just a few exceptions, fall-applied scalping level, chemical, and seed rate treatments did not significantly affect the percent green bermudagrass coverage during either the first (Table 1) or second (Table 2) year. One exception during the bermudagrass transition period was the 7 July, 1997 rating date when the severe scalping level treatment had significantly more percent green bermudagrass coverage (90.2) than the moderate scalping level treatment (87.4). The difference of $2.8 \%$, however, was not large enough to have practical importance. Other significant differences occurred between chemical treatments on 14Apr., 1997 (Table 1) and among seed rate treatments on 11 Nov. 1997 and 13 Jan. 1998 (Table 2). The largest percent difference from those was $5.6 \%$, still a moderate change.

The significant interactions were scalping level by seed rate on 28 May 1997 (Table 1) and, from Table 2, scalping level by chemica on 17 Mar. 1998, chemical by seed rate on 28 Apr. and 19 May 1998, and scalping level by chemical by seed rate on 2 Dec. 1997. The means (data not shown) did not reveal any important results.

\section{Discussion}

Data from this study showed that fall-applied scalping level, chemical, and seed rate treatments did not affect spring transition of an overseeded 'Tifgreen' bermudagrass green during two consecutive years. Also, these treatments did not affect visual turfgrass quality during the second year.

Results from this study were unexpected. Unfortunately, there are few relevant published reports that enable comparisons among studies. In terms of comparing results of scalping level treatments from the current study to work of others, Johnson (1986) conducted a study to determine the effects of fall-applied, sequential vertical mowing and ethofumesate treatments on an overseeded 'Tifway' bermudagrass green. Vertical mowed treatments included none low (25\% leaf removal), and high $(60 \%$ lea removal) intensity before overseeding with perennial ryegrass. Ethofumesate applications were made at the time of overseeding in October or delayed until bermudagrass was dormant in November. In terms of significantly reducing spring transition, results showed that 1) high intensity vertical mowing had a significant effect on plots treated or not with ethofumesate, 2) low intensity vertical mowing had a significant effect only on plots treated with ethofumesate, and 3) ethofumesate had an effect only when applied at time of overseeding. In terms of slowing spring transition, there does not appear to be a consistent effect between scalping level treatments of the current study and vertical mowing treatments of Johnson (1986). One possible explanation for

Table 1. Percent green bermudagrass coverage during 1997 as influenced by scalping level, chemical, and seed rate treatments applied during Fall 1996.

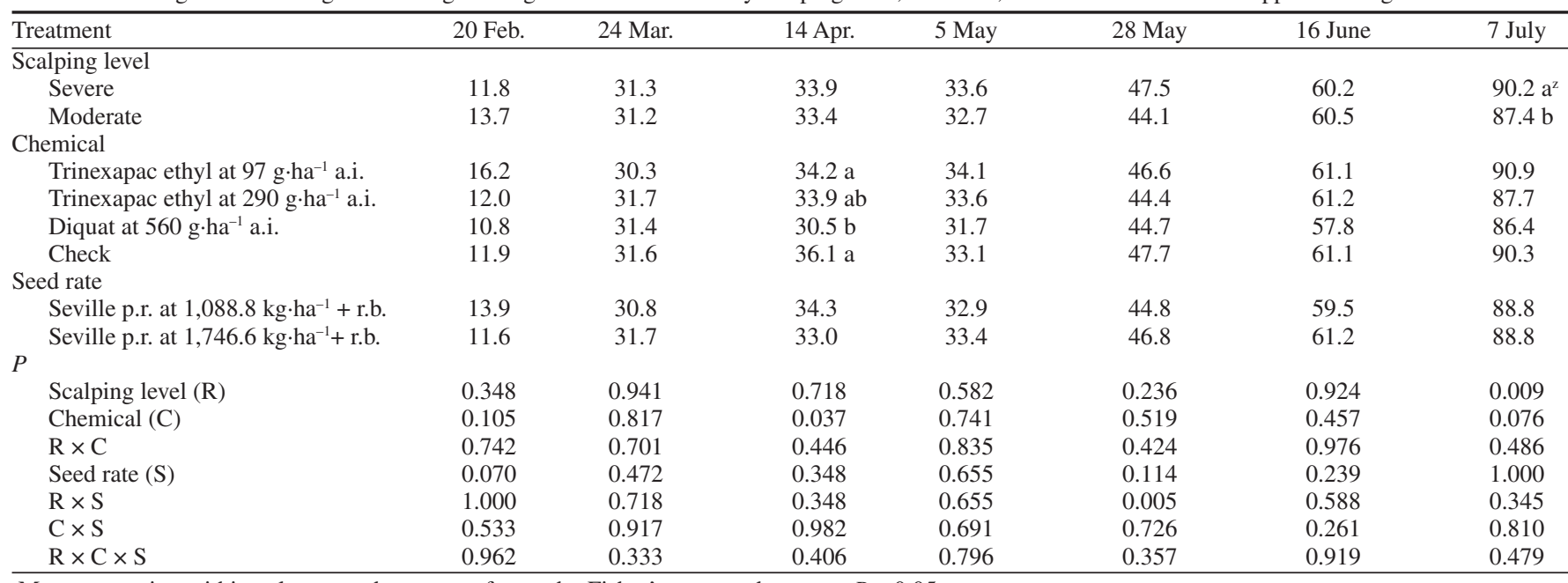

${ }^{\mathrm{z}}$ Mean separation within columns and treatment factors by Fisher's protected LSD test, $P=0.05$.

HortScience Vol. 39(3) June 2004 
Turf Management

Table 2. Percent green bermudagrass coverage during late 1997 and 1998 as influenced by scalping level, chemical, and seed rate treatments applied during Fall 1997.

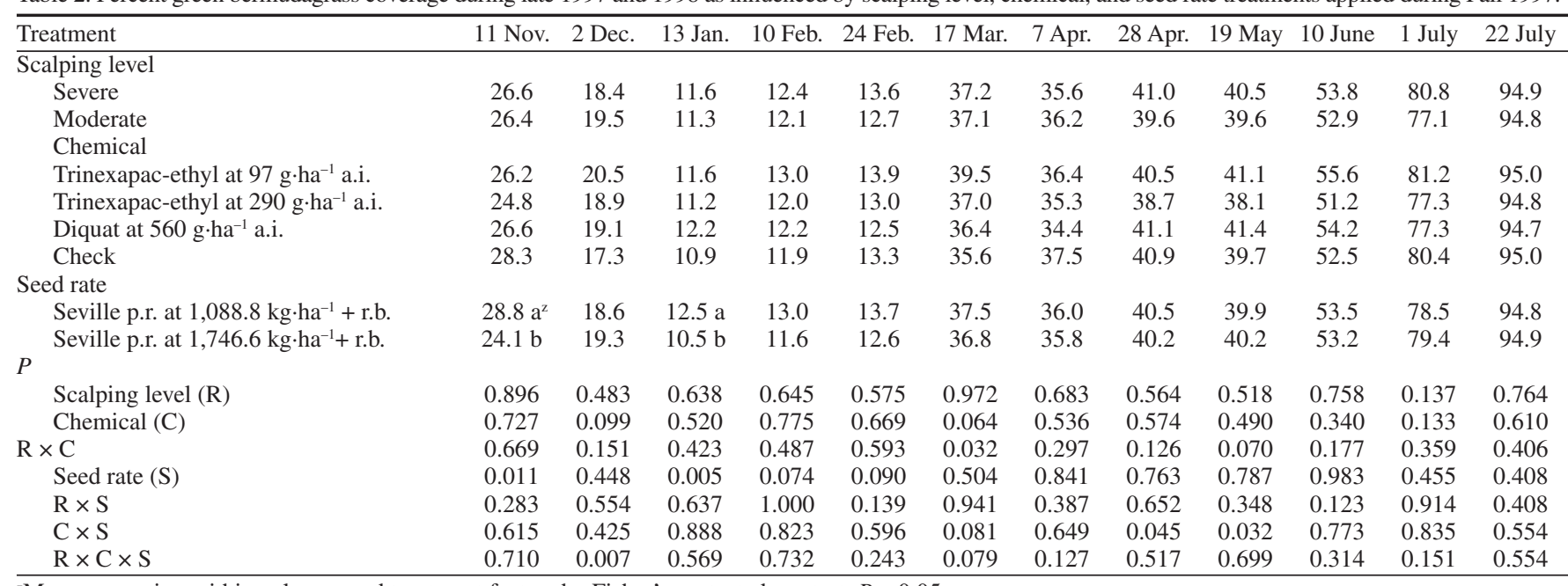

${ }^{2}$ Mean separation within columns and treatment factors by Fisher's protected LSD test, $P=0.05$.

this difference is that a no scalping treatment was not included in the current study which may have resulted in a significant scalping level treatment effect.

In terms of comparing results of chemical treatments from the current study to work of others, we were unable to find published reports that describe the effects of trinexapac-ethyl or diquat applications during seedbed preparation of overseeded bermudagrass greens on spring transition.

In terms of comparing results of seed rate treatments from the current study to work of others, Mazur and Rice (1999) reported that increasing perennial ryegrass seeding rate from 900 to $1,800 \mathrm{~kg} \cdot \mathrm{ha}^{-1}$ resulted in more rapid ryegrass establishment and a linear increase in turf quality. They also reported that spring transition to bermudagrass was slowed at high (1,500 to $\left.1,800 \mathrm{~kg} \cdot \mathrm{ha}^{-1}\right)$ seeding rates, with significantly more ryegrass present in late May. In terms of significantly slowing spring transition, there does not appear to be a consistent effect between the current study and Mazur and Rice (1999). One possible explanation for this difference is that the seed rate treatments in the current study included $458.6 \mathrm{~kg} \cdot \mathrm{ha}^{-1}$ rough bluegrass, which may have dominated any effect due to the difference between high and low seed rate treatments, 1,746.6 and 1,088.8 $\mathrm{kg} \cdot \mathrm{ha}^{-1}$ perennial ryegrass, respectively. During the current study, turfgrass coverage and visual appearance was, in all practical purposes, due to rough bluegrass.

In conclusion this 2-year study, conducted in the low desert climate of southern Calif. did not find that spring transition of an overseeded
'Tifgreen' bermudagrass green was influenced by fall-applied treatments associated with seedbed preparation and overseeding. However, there may be a need for more research involving a wider range of treatment levels.

\section{Literature Cited}

Beard, J.B. 2002. Turf management for golf courses. Ann Arbor Press. Chelsea, Mich.

Dest, W.M. and K. Guillard. 1987. Nitrogen and phosphorus nutritional influence on bentgrassannual bluegrass community composition. J. Amer. Soc. Hort. Sci. 112:769-773

Dunn, J.H., C.J. Nelson, and J.L. Sebaugh. 1980. Characterization of thatch, rhizomes, carbohydrates, and spring deadspot in twenty cultivars of bermudagrass. J. Amer. Soc. Hort. Sci. 105:653-657.

Dunn, J.H. and C.J. Nelson. 1974. Chemical changes occurring in three bermudagrass turf cultivars in relation to cold hardiness. Agron. J. 66:28-31.

Gaussoin, R.E. and B.E. Branham. 1989. Influence of cultural factors on species dominance in a mixed stand of annual bluegrass/creeping bentgrass. Crop Sci. 29:480-484.

Gill, W.J., W.R. Thompson, and C.Y. Ward. 1967. Species and methods for overseeding bermudagrass greens. Golf Superintendent 35(5):10, 13, 15, 17.

Horgan, B.P. and F.H. Yelverton. 2001. Removal of perennial ryegrass from overseeded bermudagrass using cultural methods. Crop Sci. 41:118-126.

Ibitayo, O.O. and J.D. Butler. 1981. Cold hardiness of bermudagrass and Paspalum vaginatum $\mathrm{Sw}$. HortScience. 16:683-684

Johnson, B.J. 1994a. Influence of diclofop and dithiopyr on spring transition of a bermudagrass (Cynodon dactylon) green overseeded with perennial ryegrass (Lolium perenne). Weed Technol. 8: 207-211.
Johnson, B.J. 1994b. Fenarimol tolerance of roughstalk bluegrass overseeded in bermudagras greens. Agron. J. 86:519-522.

Johnson, B.J. 1990. Effects of pronamide on spring transition of a bermudagrass (Cynodon dactylon) green overseeded with perennial ryegrass ( $\mathrm{Lo}$ lium perenne). Weed Tech. 4:322-326.

Johnson, B.J. 1988. Influence of herbicides on bermudagrass greens overseeded with perennial ryegrass. J. Amer. Soc. Hort. Sci. 113:662-666.

Johnson, B.J. 1987. Tolerance of overseeded perennial ryegrass to selected tricalcium arsenate reatments. HortScience 22:886-888.

Johnson, B.J. 1986. Response to vertical mowing and ethofumesate treatments for annual bluegrass control in bermudagrass turf. Agron. J. 78:495-498.

Krans, J.V., H.W. Philley, J.M. Goatley, and M. Tomaso-Petterson. 1992. The relationships of rhizome density, sod strength, and spring greenup in bermudagrass. Agron. Abstr. 84:172.

Mazur, A.R. 1988. Influence of plant growth regulators on transition of bermudagrass putting green overseeded with perennial ryegrass. J.Amer. Soc. Hort. Sci. 113:367-373.

Mazur, A.R. and J.S. Rice. 1999. Impact of overseeding bermudagrass with various amounts of perennial ryegrass for winter putting turf. HortScience 34:864-866.

Mazur, A.R. and D.F. Wagner. 1987. Influence of aeration, topdressing, and vertical mowing on overseeded bermudagrass putting green turf. HortScience 22:1276-1278.

Reeves, S.A., G.G. McBee, and M.E. Bloodworth 1970. Effect of N.P.K tissue levels and late fall fertilization on the cold hardiness of Tifgreen bermudagrass (Cynodon dactylon $\times$ C. transvaalensis). Agron. J. 62:659-662.

Steel, R.G.D. and J.H. Torrie. 1960. Principles and procedures of statistics. McGraw-Hill Book Co., New York. 